\title{
A Note on Conventions
}

This book works between several languages and traditions, some of which may be obscure to the reader.

Chinese reign dates and Hijri dates have both been converted to their equivalents in the Gregorian calendar. Most of this story takes place during the Tongzhi (1861-75, abbreviated in this book's endnotes as “TZ”), Guangxu (1875-1908, or "GX"), and Xuantong (1908-11, or "XT") reigns, and in the years 1280-1330 of the Hijri. It continues in the era of the Republic of China (Minguo, or "MG").

Women in Qing documents were frequently identified only by their surname, followed by the word shi. "Wei shi," then, is roughly equivalent to "Ms. Wei" or "the woman Wei."

Age as recorded in Chinese sources is reckoned in sui. A person is one sui old at the moment of birth, and consequently may be one or two years older in Western "years old" than they would be in sui.

Yamen was the term used for the office of any Qing official. Terminology for Qing ranks and titles in general follows that provided by Brunnert and Hagelstrom, which although somewhat antiquated is comprehensive enough to include the terms of local administration and reflects a certain understanding of the Qing government around the time this story took place. ${ }^{1}$ In the late Qing, Turpan was a "directly administered prefecture" (zhili ting), and its highest official a "first-class subprefect." I therefore refer to him as "the prefect." Under the Turpan prefect was the subordinate 
office of the Pichan "subdistrict magistrate" (xunjian). In 1902, Pichan was elevated to the level of a "county" (xian), forming Shanshan County, and the subdistrict magistrate was made a full county magistrate. After the Xinhai Revolution of 1911 and the fall of the Qing, Turpan was made a county equal to Shanshan, and its prefect a magistrate.

Turpan was located in one of four administrative units called "circuits" (dao), each led by an "intendant" (daotai). Turpan was in the Zhendi Circuit of Xinjiang province, and the others were the Aksu, Kashgar, and IliTarbaghatai Circuits. Those intendants reported to a provincial government in the capital of Dihua (modern Ürümchi) headed by a governor (xunfu). The governor's immediate subordinates included a financial commissioner (buzhengshi) and a judicial commissioner (anchashi).

I have chosen to present names and words in the various languages in this book in ways that readers will hopefully not find alienating. Chinese is transliterated according to the Pinyin system. For Arabic, Persian, and Chaghatay I use a modified version of the system of the International Journal of Middle Eastern Studies; for Manchu, Möllendorff; and Japanese, Hepburn. Diacritics have been minimized as much as possible.

As minority people in China know well, using Chinese to render long names that include sounds not encountered in Mandarin often yields even longer and unwieldier results. This was true in late-Qing Xinjiang as well, where the Turkic and Islamic names that we encounter in Chinese in the archive sometimes barely resemble what people called themselves. Helpfully, I have found documents in the Turpan archive that present TurcoIslamic names and their Chinese equivalents side by side, providing a relatively systematic understanding of how Turkic speech sounds were rendered into Chinese. On that basis, I present the most likely Turko-Islamic name, if it can be deciphered, alongside its Chinese transliteration in the first instance, for example, "Rawżallah (Ruozangle)." I follow a similar system for place names, in which case I favor the name as it was rendered in Chaghatay over that used in Chinese. 